\title{
Review on the transmission porcine reproductive and respiratory syndrome virus between pigs and farms and impact on vaccination
}

\author{
Emanuela Pileri ${ }^{1,2}$ and Enric Mateu ${ }^{1,2^{*}}$ (D)
}

\begin{abstract}
Porcine reproductive and respiratory syndrome (PRRS) is considered to be one of the most costly diseases affecting intensive pig production worldwide. Control of PRRS is a complex issue and involves a combination of measures including monitoring, diagnosis, biosecurity, herd management, and immunization. In spite of the numerous studies dealing with PRRS virus epidemiology, transmission of the infection is still not fully understood. The present article reviews the current knowledge on PRRSV transmission between and within farm, and the impact of vaccination on virus transmission.
\end{abstract}

\section{Table of contents}

1 Introduction

2 Virus stability in the environment and disinfection

3 Transmission of PRRSV

3.1 Routes and methods of transmission of PRRSV

3.2 Development of viraemia and persistence in lymphoid tissues

3.3 Viral shedding

4 Factors influencing PRRSV transmission

4.1 Age of the pigs at the time of the infection

4.2 Variation in the virulence of PRRSV isolates

4.3 Immune response against PRRSV

5 Transmission and dynamics of the infection within herds

6 Quantification of PRRSV transmission

7 Vaccination and PRRSV transmission

8 PRRSV transmission between farms

9 Conclusions

\section{Introduction}

Porcine reproductive and respiratory syndrome (PPRS) has become one of the most important diseases of intensive pig production worldwide. The economic impact of PRRS in breeding and farrowing units is caused mostly by a reduction in the number of weaned pigs and by an impairment of the farrowing rates. Infection in growingfinishing pigs may increase secondary infections and mortality rates, as well as resulting in retarded growth, a high dispersion of weights at slaughter age, and increased antimicrobial usage. In 2005, the total annual cost of PRRS outbreaks in USA was estimated to be about USD 560 million, which comprised USD 67 million for the breeding-farrowing phase, USD 201 million for the nursery phase and USD 292 million for the grower-finisher phase of production [1]. More recently, Holtkamp et al. [2] calculated a cost of USD 663 million/year for the United States, representing a 10\% increase compared to Neumann et al. [1]. In Europe, average losses related to PRRS outbreaks were estimated by Nieuwenhuis et al. [3] in $126 € /$ sow, slightly more than the USD 121 /sow reported by Neumann et al. [1].

The negative impact of PRRS on the economic margin of pig production has stimulated the efforts to control and eventually eradicate the disease. It is assumed that 
control of PRRS virus (PRRSV) relies on four different aspects: early diagnosis and monitoring, biosecurity, herd management, and immunisation. A deep understanding of how the virus is transmitted between animals and how it spreads in pig populations is crucial for choosing the most suitable strategies to cease viral circulation and to avoid reintroduction of the virus into the farm. Therefore, the main objective of the present paper is to review the current knowledge about PRRSV transmission, taking into account the pathogenesis of the infection as well as the host and viral factors that can influence the dynamics of transmission. Additionally, the effect of vaccination on PRRSV transmission and the usefulness of this measure to stop viral circulation are also discussed.

\section{Virus stability in the environment and disinfection}

PRRSV is a small, enveloped, positive-sense, singlestranded RNA virus that is quickly inactivated by lipid solvents, heat, drying, or at a pH below 5 or above 7 [4]. Bloemraad et al. [5] demonstrated that Lelystad virus (LV) is inactivated after $6 \mathrm{~min}$ at $56^{\circ} \mathrm{C}$ or $3 \mathrm{~h}$ at $37^{\circ} \mathrm{C}$, but it is stable for $140 \mathrm{~h}$ at $4{ }^{\circ} \mathrm{C}$ and for several months in cell culture medium at $\mathrm{pH} 7.5$ at temperatures between -70 and $-20{ }^{\circ} \mathrm{C}$. With a genotype 2 isolate, Van Alstine et al. [6] showed similar results, and at $72 \mathrm{~h}$ after necropsy of experimentally infected pigs the infectious virus could only be recovered from $7 \%$ of the examined tissue samples. Finally, it has been shown in the Midwest of USA that PRRS outbreaks follow a seasonal pattern, with an onset of the epidemic in October [7]. The cause of this seasonal pattern is unclear although it could be in part related to the stability of the virus in the cold season.

As for disinfection, complete inactivation of the virus is accomplished in $1 \mathrm{~min}$ using iodine $(0.0075 \%)$ or quaternary ammonium compounds $(0.0063 \%)$ [8]. Complete inactivation of PRRSV is also achieved with chlorine, although a higher disinfectant concentration $(0.03 \%)$ and a longer exposure time (10 $\mathrm{min})$ were needed [8]. Similarly, 10 min of ultraviolet light exposure completely inactivated the virus on common farm surfaces and materials [9].

\section{Transmission of PRRSV}

\subsection{Routes and methods of transmission of PRRSV}

Pigs can be infected by either direct contact or indirectly through fomites. Exposure to PRRSV occurs by the respiratory and oral routes and through the mucosae or percutaneously. The methods involved are aerial transmission (either short or long distance), by coitus or insemination, ingestion, by contact, and by inoculation (most often iatrogenically). Vertical transmission is important during the last trimester of gestation.
The minimum infectious dose (MID) of PRRSV varies depending on the route of exposure. Hermann et al. [10] evaluated the infectious dose $50\left(\mathrm{ID}_{50}\right)$ by oral and nasal exposure. Exposure of pigs to isolate PRRSV 2 isolate VR-2332 resulted in an $\mathrm{ID}_{50}$ of $10^{5.3}$ and $10^{4.0} \mathrm{TCID}_{50}$ for the oral and intranasal route, respectively. The same authors found that inoculating pigs by the intramuscular route, the $\mathrm{ID}_{50}$ was $10^{2.2} \mathrm{TCID}_{50}$. In contrast, Yoon et al. [11] reported that $\leq 10$ PRRSV particles of the genotype 2 isolate ISU-P were enough to infect pigs parenterally. Differences in the infectivity among PRRSV isolates were also observed for other transmission routes. Thus, Cutler et al. [12] calculated that the $\mathrm{ID}_{50}$ for the aerosol exposure to genotype 2 isolate $\mathrm{MN}-184$ was less than $2 \mathrm{TCID}_{50}$ while Hermann et al. [13] reported an $\mathrm{ID}_{50}$ of $10^{3.1} \mathrm{TCID}_{50}$ for the aerosol exposure using isolate VR-2332. Regarding the sexual transmission, Benfield et al. [14] estimated the $\mathrm{ID}_{50}$ for exposure via artificial insemination to be $10^{3.3} \mathrm{TCID}_{50}$.

According to the available data, the percutaneous exposure is the route with the lowest MID. On the farm, parenteral exposure could be frequent and would include standard practices such as ear notching, tail docking, teeth clipping, and injection of drugs and vaccines. In the peak of the viraemia, infected animals have a viral load of at least $10^{3}$ to $10^{4} \mathrm{TCID}_{50} / \mathrm{mL}$ [15]. Assuming a MID between $10^{1}$ and $10^{2} \mathrm{TCID}_{50}$ for the percutaneous route, blood volumes of $1-10 \mu \mathrm{L}$ could be sufficient to produce transmission. In fact, Otake et al. [16] demonstrated that transmission of PRRSV is achieved by using contaminated needles. Likewise, Baker et al. [17] showed that transmission of MN-184 isolate can occur by using the same needle between pigs, and that the use of needlefree injection device (NFID) reduced, but did not fully prevent, this type of transmission. However, the authors were not able to identify the route of transmission in the NFID group although airborne virus was discarded since controls remained negative for the duration of the trial.

Moreover, normal pig behaviour may also result in parental exposure through bites, cuts, scrapes and/ or abrasions that occur during fighting between pigs. Bierk et al. [18] demonstrated that aggressive behaviour between infected sows and susceptible contacts may play a role in PRRSV transmission.

\subsection{Development of viraemia and persistence in lymphoid tissues}

Following exposure to the virus, replication occurs initially in permissive macrophages of lymphoid tissues at the portal of entry and then the virus rapidly spreads throughout the body by the lympho-haematic route. In a genotype 2 model viraemia started as early as $12 \mathrm{~h}$ postinfection [19] and viral load peaked in serum around 
7-10 days post-infection (dpi). The duration of viraemia varies depending on the PRRSV strain and on the age of the animal [20-23]. This general picture is similar in genotype 1 [22]. In both cases, several studies indicated that in general the period of viraemia may range from a few weeks (usually <4) in adults or grower-finishers to up to three months in very young piglets [23-26]. In adult sows, viremia may be limited to just one week as shown by Karniychuk with genotype 1 PRRSV [27]. When infecting 2-week-old piglets with a genotype 2 isolate, Wills et al. [26] detected viral RNA in serum in $1 / 28$ pigs at $251 \mathrm{dpi}$, although they could not isolate infectious virus from serum after $56 \mathrm{dpi}$.

The lungs and the lymphoid organs such as tonsils, Peyer's patches, thymus, and spleen $[15,28-30]$ are the tissues with the highest viral loads in the initial phase. In lungs the virus is usually detected from 1 day post-exposure until $28 \mathrm{dpi}[30,31]$, although persistence of virus in the lungs been described until 49 days post-exposure in young pigs [32].

The viraemic phase of the infection is followed by a period of confinement of the virus in secondary lymphoid tissues, and lower viral replication. Studies carried out with genotype 2 PRRSV showed that the virus could be isolated from oropharyngeal scrapings until $157 \mathrm{dpi}$ [33], and Horter et al. [25] found that $86 \%$ of the infected pigs (51/59) carry the virus in oropharyngeal scrapings or tonsils between 63 and 105 dpi. Viral genome can be present in serum and tonsils until 132 days after birth in piglets surviving congenital infection [34, 35]. However, the mere presence of the virus in tissues is not a direct equivalent to transmission. With regards to the potential for transmission, Allende et al. [24] in a bioassay with materials of type 2 infected pigs, showed that at $150 \mathrm{dpi}$, tonsil tissue of $2 / 5$ contained sufficient infectious virus to be transmitted. Bierk et al. [18] demonstrated that non-viraemic sows were able to transmit the infection by direct contact with PRRSV-naïve sows at 49,56 , and $84 \mathrm{dpi}$. Likewise, non-viraemic pigs transmitted the virus to naïve sentinels up to $62 \mathrm{dpi}$ [36]. Conversely, non-viraemic sows were still able to transmit the infection by contact with naïve sows at periods between 49 and 86 dpi [18]. Charpin et al. [37] showed that with genotype 1 PRRSV, piglets reach a peak of infectiousness around $9 \mathrm{dpi}$, then decreasing until $42 \mathrm{dpi}$. Transmission of PRRSV from congenitally infected piglets to sentinel animals was observed up to 112 days after birth [35]. In summary, it can be assumed that contagiousness decreases with time, but transmission is possible under natural conditions up to 3 months in horizontally infected pigs, while for congenitally infected animals the contagiousness period may well exceed this period.
Regarding the ability of chronically infected pigs to transmit the virus to susceptible animals, it is worth noting that circumstances causing stress such as farrowing, regrouping etc., might induce a reactivation of viral replication and shedding. For example, Albina et al. [38] demonstrated reactivation of PRRSV shedding after corticosteroid treatment at 15 weeks after the initial seroconversion of the animal.

\subsection{Viral shedding}

The development of viraemia and the body distribution of susceptible macrophages lead to the shedding of PRRSV by multiple routes. In fact, the presence of the virus in nasal secretions, saliva, urine, faeces, mammary gland secretions, and semen is well documented in several studies [19, 39-52].

Regarding nasal shedding, it seems to be strain dependent, at least with genotype 1 . For the prototypical type 1 isolate Lelystad virus, Duan et al. [15] showed that nasal shedding was scarce achieving isolation only in $4 / 8$ pigs at 3 days post-inoculation and in $1 / 8$ at 7 days post-inoculation and always at low titres. Charpin et al. [37] using a genotype 1 PRRSV strain indicated that the viral load in nasal secretions of inoculated piglets increased very rapidly, reaching a maximum at $2 \mathrm{dpi}$, and then decreased steadily until $48 \mathrm{dpi}$. No RT-PCR positive nasal swabs were detected after 49 dpi [37]. Further work done at the University of Ghent has shown that the ability of a given isolate for infecting different subsets of potentially susceptible cells in the nasal mucosa is the critical factor for nasal shedding $[53,54]$ (see also Sect. 4.2).

With genotype 2 Rossow et al. [47] reported nasal secretion in only $1.9 \%(2 / 105)$ of the nasal swabs collected from experimentally inoculated pigs during a 28-day-observation period [47], and no virus was isolated in nasal secretions of experimentally infected gnotobiotic pigs [19]. Christianson et al. [39] inoculated sows with genotype 2 virus around 50 days of gestation with the genotype 2 VR-2332 isolate. Shedding by the nasal route was observed from 3 to $9 \mathrm{dpi}$, while faecal swabs were positive for viral isolation at 2, 4-6, 8, and 9 dpi. Conversely, Yoon et al. [51] described intermittent nasal and faecal shedding until $38 \mathrm{dpi}$ in experimentally inoculated piglets. Rossow et al. [47] isolated VR-2332 only sporadically from faecal swabs of piglets at $28 \mathrm{dpi}$, whereas the virus was not detected in faeces of experimentally infected gnotobiotic pigs [19]. Shedding in faeces is irregular [47].

Shedding in oral fluids seems to be more constant but most data are restricted to genotype 2 virus. Thus, Wills et al. [50] isolated the virus at least once in 5/6 inoculated pigs $(83.3 \%)$, and shedding was detected up to 
$42 \mathrm{dpi}$, although intermittently [50]. Prickett et al. [46] assessed viral shedding in oral swabs, as well as in penbased oral fluids, over a 63-day period in pigs inoculated with a genotype 2 PRRSV strain. Oral fluids were positive by RT-PCR from 3 dpi to $4-5$ weeks post-inoculation, with sporadic positive results thereafter. Moreover, viral load in serum and oral fluid samples followed a similar pattern, although oral fluids usually had a lower concentration of virus [46]. Conversely, Kittawornrat et al. [44] found that serum contains equal or higher concentration of virus than oral fluids for the first $14 \mathrm{dpi}$, while the amount of virus was higher in oral fluids from $21 \mathrm{dpi}$ onwards. In all cases, shedding in oral fluids is detected early in the course of infection $(76-100 \%$ of qRT-PCR positive samples at $2-4 \mathrm{dpi}$, respectively), regardless of the viral isolate used as inoculum [44].

The presence of virus in oral fluids, and the relative constancy of this shedding over time, may have also important implications in the transmission of PRRSV. As the MID required for the parenteral route is the lowest, common pig behaviours such as fighting, tail-biting, and ear-biting could result in effective transmission. It would be worth studying whether the actions for enhancing pig welfare may result in decreased transmission of PRRSV.

As regards shedding in semen of infected boars, viral genome was detected by RT-PCR as early as $3 \mathrm{dpi}$, and up to $92 \mathrm{dpi}$ in $1 / 4$ boars inoculated with the VR-2332 isolate [40]. Infectious virus in semen was intermittently detected by viral isolation and/or swine bioassay from 3 up to 43 dpi in experimentally infected boars, although viraemia lasted less than 14 days [40, 41, 45, 48]. Moreover, PRRSV was isolated from the bulbourethral gland of one boar at $101 \mathrm{dpi}$, suggesting that the male reproductive tract could be a long-term source of the virus, and that viremia is not an adequate indicator of the potential contagiousness of a boar [40].

PPRSV can be also shed in urine $[47,50]$ and mammary gland secretions $[43,49]$. In experimentally infected sows, genotype 2 PRRSV was detected by RT-PCR in the first day of lactation [43]. Wagstrom et al. [49] showed that naïve sows inoculated late in gestation shed PRRSV in colostrum and milk, but only for a limited number of days and in low concentrations, as determined by virus isolation and titration. In addition, vaccination of sows seemed to prevent shedding during subsequent lactations, and the virus was not detected in any of the milk samples collected from 181 sows of 8 endemically infected herds. These results suggest that colostrum and milk can be a source of virus for the offspring, but their contribution to PRRSV transmission is probably secondary [49]. Fecal shedding seems to be irregular.

Infected pigs produce contaminated aerosols when breathing, sneezing or coughing. Cho et al. [55] inoculated two groups of pigs intranasally with the genotype 2 isolates $\mathrm{MN}-30100$ and the $\mathrm{MN}-184$ isolates, respectively. Aerosol samples were then collected on alternate days from 1 to $21 \mathrm{dpi}$ and were analysed by qRT-PCR. Results showed that a small number of pigs inoculated with PRRSV MN-30100 shed intermittently throughout the sampling period, whereas more consistent shedding was observed in a larger number of pigs inoculated with PRRSV MN-184. Although the difference in the mean concentrations of PRRSV RNA in aerosols from pigs infected with PRRSV MN-30100 or PRRSV $\mathrm{MN}-184$ was not significant, the logistic regression analysis showed that inoculation with PRRSV MN-184 resulted in a significantly higher likelihood of aerosol shedding than inoculation with PRRSV MN-30100. These results supported the notion that PRRSV transmission by aerosol is dependent on the PRRSV strain involved.

\section{Factors influencing PRRSV transmission}

In the following sections, the most relevant aspects concerning the factors influencing the PRRSV transmission between pigs are summarised.

\subsection{Age of the pigs at the time of the infection}

Klinge et al. [21] showed that 3-week-old piglets had significantly longer viraemias than finishers or adult pigs, regardless of the PRRSV isolate used as inoculum. Likewise, 2-month-old pigs had significantly higher viral loads in lymph nodes, lungs, and tracheobronchial swabs than 6-month-old animals, regardless of the virulence of the challenge strain $[21,55]$. In addition, Thanawongnuwech et al. [56] showed that pulmonary macrophages from 4-week-old pigs yielded higher virus titres than pulmonary macrophages from 4-month-old pigs. All the previous data present indirect evidence of a higher contagiousness of piglets compared to finishers or adult pigs, although a precise evaluation is lacking. This can be relevant for the control of the infection in farrow-to-finish farms, in particular regarding the potential re-infection of sows or new-born pigs from nurseries.

\subsection{Variation in the virulence of PRRSV isolates}

Cho et al. [20] showed that inoculation with the genotype 2 highly virulent strain $\mathrm{MN}-184$ resulted in significantly higher viral loads in serum and tonsils than inoculation with the low virulence isolate MN-30100. Also, MN184-inoculated pigs produced contaminated aerosols for a longer period [55]. Likewise, boars infected with MN-184 isolate showed higher viral titres in serum and shed significantly higher amounts of virus in oral fluids at 7-14 dpi than pigs inoculated with isolates of lesser virulence [44]. Increased replication efficiency and higher viral titres in serum were also observed for the highly 
pathogenic HuN4 [57] and Lena [52] strains, although in these cases the viral shedding was not assessed. Moreover, in several studies by Frydas et al. $[53,54,58]$ it was shown, at least for genotype 1 , that different isolates replicate to a different extent in the nasal mucosa, and this may have an influence on the formation of aerosols. Collectively, these data suggest that pigs infected with highly virulent strains could shed higher amounts of virus than pigs infected with low virulent strains, and that the replication in nasal mucosa varies between isolates. However, experiments aimed at comparing the transmissibility of PRRSV strains of different virulence are still lacking.

\subsection{Immune response against PRRSV}

The immune response against the virus is probably the most important factor influencing the course of the infection, and consequently the susceptibility and infectiousness of pigs. The development of neutralising antibodies (NA) and/or of a cell-mediated immunity (CMI) have been related with the clearance of PRRSV infection or pre-exposure protection [23, 59-63]. Nevertheless, since viraemia can be resolved without the development of neutralising antibodies or strong CMI, the correlates of protection are still not well understood [64-68]. In addition, the genetic/antigenic diversity of PRRSV and the idiosyncrasy of each individual are also known to play a role. In fact, in general terms, both virological and clinical protection is good in the case of homologous challenge [69], whereas it is only partial for heterologous challenges, although genetic similarity between the immunising and the challenge strain is not fully predictive of the degree of protection [59, 70-73]. Although this topic is beyond the scope of the present review, it will be discussed with more details in the Sect. 4.2.

\section{Transmission and dynamics of the infection within herds}

When PRRSV enters into an immunologically naïve herd, all pigs are affected, and a clinical outbreak usually occurs. In a typical farrow-to-finish farm, viral circulation begins in one or more stages of production, commonly in the breeding herd, and then the virus spreads to all production stages in about 2-3 weeks. Sows can transmit the virus to their offspring by the trans-placental route and/ or by direct contact during lactation.

Piglets infected congenitally or very early in life can harbour the virus for several months, and can contribute to the spread of the infection in the following productive stages. As the infection progresses, the proportion of immune pigs increases, and that of susceptible animals decreases. This leads to the decline phase of the epidemic in 1-5 months, depending on the herd size and the time needed to achieve a protective immunity in the majority of pigs [74-76]. At this point, the infection usually becomes endemic, although in some small farms it may fade out just because of the exhaustion of susceptible pigs [77]. In fact, the transmissibility of the virus, the duration of the infectious period, and the existence of susceptible pigs in the population mainly determine the spontaneous extinction of a virus in a population. Nodelijk et al. [78] estimated, by using a Monte Carlo simulation, that the average time for type 1 PRRSV to fade-out was about 6 years in a closed herd of 115 sows, whereas it was as long as 80 years in a closed herd of 230 sows. These estimations are in accordance with those of Evans et al. [79] indicating that the persistence of the infection is more likely as the herd size increases, and when the gilt pool is not properly isolated from sows. In addition, PRRSV fade-out seems less likely to occur when the infection is established in the farrowing house and in piglets due to the retrograde transmission from infected nurseries or finishers to the breeding herd [79].

The maintenance of the infection within a farm is basically due to the combination of animals with long-term infection and the continual availability of susceptible pigs. The latter can be added to the population by replacement, by birth of piglets from seronegative sows, by loss of passive immunity in young pigs, or by loss of active immunity in previously infected pigs [77]. As a result, PRRSV can circulate in the farm for several years. For instance, a longitudinal study conducted in a Dutch breeding herd by Nodelijk et al. [78] shown that seroprevalence in sows during an acute outbreak was $86-95 \%$, and that sows that initially escaped the infection did seroconvert at a later stage, indicating the existence of sub-populations that have a low level of viral circulation. In sows, the infection cycle can be maintained by transmission between them, but also by anterograde transmission of the virus from nurseries or finishing units [79].

It is generally acknowledged that most infections are subclinical in chronically infected herds. For instance, Bilodeau et al. [80] detected viral circulation in a farrowto-finish farm using sentinel pigs several months after the cessation of the outbreak. The subclinical infection was also detected in a neighbouring barn that had never experienced clinical PRRS, and was situated $50 \mathrm{~m}$ from the main farm. Likewise, Stevenson et al. [76] monitored type 2-infected 6-8 week-old piglets of two farrow-tofinish farms that experienced a reproductive outbreak 2.5 years before. They found that most of the necropsied pigs were positive in lungs and spleen by viral isolation, confirming that PRRSV was circulating in nursery pigs despite both farms being clinically "healthy" for several years since the original outbreaks. 


\section{Quantification of PRRSV transmission}

The knowledge of the dynamics of PRRSV circulation within a herd and the quantification of the virus transmission in a pig population are key points for the development of prevention and control strategies of the infection, as well as for estimating the impact of such interventions. Unfortunately, there are currently only few studies available on this topic. The reproduction rate (R) is usually used for quantification purposes. $R$ is defined as the mean number of cases infected by one infectious case [81], and is equal to the duration of the infectious period multiplied by the transmission parameter $\beta$ (probability of contact between infectious and susceptible by probability of transmission in case of contact per unit of time). The higher the R-value, the greater and faster is the spread in the population. Moreover, when $\mathrm{R}<1$, the infection tends to fade-out with time in the assumption of a large and homogeneous population.

Nodelijk et al. [78] quantified the transmission within a herd using the serological data obtained from a longitudinal study of a type 1-infected closed breeding farm (115 sows) that experienced a major outbreak 6 years before. The results indicated that during the first wave of the epidemic, seroconversion was observed in $80 \%$ of the sows and $49 \%$ of rearing pigs, respectively. Four years after the epidemic, and until the end of the study none of the pigs seroconverted, and all sera were negative for PRRSV, indicating the total fade-out of the virus. In the same study, the reproduction rate was estimated to be $3.0\left(\mathrm{CI}_{95 \%}\right.$ 1.5-6.0) for sows devoid of previous immunity, assuming that the infectious periods of pigs lasted 56 days, and that there was no life-long immunity after infection. Charpin et al. [35] estimated an $\mathrm{R}$ of $2.6\left(\mathrm{CI}_{95 \%}\right.$ 1.8-3.3) for naive piglets, using an experimental model of transmission of type 1 PRRSV by contact between inoculated and susceptible pigs introduced at different times post-infection. In that same work, the mean duration of contagiousness was estimated to be 14.8 days, with a peak of infectivity at $9 \mathrm{dpi}$, and a negligible probability of transmission after $42 \mathrm{dpi}$, although inoculated piglets were positive using RT-PCR in sera up to $77 \mathrm{dpi}$.

The reproduction rate of a genotype 1 PRRSV was also assessed in growing pigs by our research group [82]. We used a model of transmission by contact that mimicked natural conditions: groups of five susceptible pigs (six replicates in total) were co-mingled and each left in contact with an experimentally inoculated pig for a period of 21 days. The development of viraemia was monitored using quantitative real time-PCR. Assuming the mean duration of viraemia as the infectious period of the animals belonging to the same contact group (including the inoculated pig), we estimated an $\mathrm{R}$ value of $2.78\left(\mathrm{CI}_{95 \%}\right.$ 2.1-3.4) for growing pigs. More recently, Rose et al. [83] also performed an experiment to quantify the transmission of genotype 1 PRRSV in piglets. In this case, two susceptible pigs were kept in contact with two experimentally inoculated piglets (six replicates in total) for 49 days and the serum monitored by RT-PCR. They found that the mean period of contagiousness, calculated on the basis of the duration of viraemia, was 22.6 days, and that $\mathrm{R}$ for piglets was $5.4\left(\mathrm{CI}_{95 \%} 2.9-9.0\right)$.

Overall, it can be concluded that the $\mathrm{R}$ for genotype 1 PRRSV could range from approximately 2 to 5 in naïve pigs. Compared to other common swine pathogens, such as classical swine fever virus $(R=15)$ [84], PRRSV does not seem to be transmitted that easily. There are few values for genotype 2 or for subtypes 2-4 of genotype 1 . In general, type 2 is thought to comprise strains of higher virulence [85] than type 1 , at least for subtype 1 .

\section{Vaccination and PRRSV transmission}

Vaccination of sows and piglets is one of the strategies commonly used for controlling PRRS, together with management and biosecurity measures. At present, several commercial attenuated (modified live vaccines, MLV) or inactivated (IV) vaccines, based on both genotype 1 and genotype 2 PRRSV strains are available. Protection afforded by these vaccines has to be evaluated at both individual and population levels. In the first case, the main objective of vaccination is to protect pigs from the infection and reduce clinical signs, whereas at population level, the aim of vaccination strategies for controlling PRRS is also to reduce the economic losses associated with the disease and to stop virus transmission. Vaccination strategies with MLV are currently predominant. Modified live vaccines are able to replicate in the host, and induce an immune response similar to that induced by mildly virulent PRRSV isolates.

As mentioned above, the virological and clinical protection afforded by MLV vaccination is considered partial against a heterologous PRRSV strains; however, in general, vaccinated pigs experience a viraemia of shorter duration compared to naïve counterparts. In any case, given the genetic diversity of PRRSV [86] most, if not all, challenge situations in the field can be considered as heterologous.

Stadejek et al. [87] evaluated the efficacy of MLV vaccination in a farrow-to-finish herd where a Polish wild type PRRSV strain was circulating for several years prior to the start of the vaccination program of PRRS control. Twelve piglets of that farm were vaccinated with a genotype $1 \mathrm{MLV}$ at 14 days of age, and then were followedup until 132 days of life. At 68-92 days post-vaccination, only two pigs had become infected with the field strain, despite the fact that the MLV and the wild type of the farm were only $82.6 \%$ similar (ORF5). Similarly, Martelli 
et al. [88] assessed the efficacy of vaccination of piglets against natural exposure to a PRRSV field strain belonging to the Italian cluster of genotype 1 PRRSV ( $8 \%$ of identity with the ORF5 of the MLV). In the post-exposure period, wild type virus was only detected in $59 \%$ of the sera of vaccinated pigs, and also clinical signs were significantly reduced in vaccinated animals compared to the unvaccinated ones.

As previously commented, at a population level, the efficacy of current vaccines cannot be only evaluated in virological terms. In epidemiological terms, the goal of vaccination is also to stop or decrease viral transmission within a farm. The ceasing of virus transmission in a herd could be achieved by vaccination, if the MLV has the ability to reduce the susceptibility of pigs against the infection and, at the same time, is capable of reducing the contagiousness of the individuals that eventually became infected. In this sense, the potential efficacy of MLV vaccines in the field can be estimated indirectly, by assessing the biological parameters related to transmission (i.e. duration of viraemia and shedding of the virus, number of chronically infected pigs etc.), and directly, by determining the reproduction rate of PRRSV.

Cano et al. [89] demonstrated that repeated immunisations with MLV vaccine in pigs previously infected with a homologous isolate significantly reduced the number of persistently infected pigs at $127 \mathrm{dpi}$, and also reduced the viral shedding after $97 \mathrm{dpi}$, although this strategy was not capable of completely eliminating the circulation of the wild type virus. In a similar study, Linhares et al. [90] showed that vaccination of pigs after challenge with type 2 PRRSV significantly reduced viral shedding in oral fluids and the presence of virus in the air, although the magnitude and duration of viraemia in vaccinated pigs was similar to the unvaccinated ones. Cano et al. [91] also observed a reduction in PRRSV shedding, but not in the proportion of chronically infected pigs, for type 2 virus after heterologous vaccination.

Although the abovementioned works demonstrated the efficacy of mass vaccination in reducing the biological parameters related to the virus transmission, few studies have dealt with the assessment of $R$ in vaccinated and naïve pigs. Nodelijk et al. [92] were the first to evaluate the effect of vaccination on PRRSV transmission. However, they used a genotype 2 MLV and a genotype 1 challenge virus (LV), thus being a worst-case scenario. The authors performed three different trials. In experiment $A, 5$ vaccinated $(V)$ pigs and 5 non-vaccinated ones $(\mathrm{NV})$ were challenged with $\mathrm{LV}$ and then co-mingled with another $5 \mathrm{~V}$ and $5 \mathrm{NV}$, respectively. In experiment $\mathrm{B}, 1 \mathrm{~V}$ pig was inoculated with LV and placed in contact with another $9 \mathrm{~V}$ pigs. The same protocol was used for NV pigs. Finally, in trial C, transmission of PRRSV in 10 pairs of vaccinated pigs was compared with 10 pairs of nonvaccinated pigs by means of multiple one-to-one experiments. Most vaccinated pigs $(>60 \%)$ became infected in experiments $\mathrm{A}$ and $\mathrm{B}$, and all of them became viraemic in experiment $C$. Thus, the $R$ value in vaccinated pigs, as estimated from the pooled data of trials A and B, was 1.5 $\left(\mathrm{CI}_{95 \%}\right.$ 0.7-44.8), whilst it could not be determined (infinite) for NV pigs. The study failed, therefore, in demonstrating a significant reduction of PRRSV transmission after vaccination. However, considering that the vaccine and challenge strains were of different genotypes and that pigs were inoculated intranasally, the $R$ value was probably overestimated. This phenomenon is partially confirmed by the evidence that $\mathrm{V}$ inoculated pigs had a significantly longer duration of viraemia and higher viral loads compared to $\mathrm{V}$ pigs infected by contact.

Mondaca-Fernández et al. [93] performed another study on the efficacy of vaccination in reducing type 2 PRRSV transmission. In that case, animals were vaccinated with a genotype $2 \mathrm{MLV}$, and also challenged with a genotype 2 PRRSV, the MN-30100 isolate. The authors failed in their objective, since the challenge strain was found to be little contagious, as indicated by the lack of infection in the exposed NV pigs. Thus, the $\mathrm{R}$ values were $0.59\left(\mathrm{CI}_{95 \%} 0.13-3.21\right)$ and $0.26\left(\mathrm{CI}_{95 \%} 0.01-2.26\right)$ for the vaccinated and non-vaccinated groups of pigs, respectively. The difference was not significant, but considering the low transmissibility of the challenge strain, it can be argued that PRRSV transmission could not be properly assessed.

Our experimental study for assessing the PRRSV transmission by contact [82] was the first work in which a significant reduction of the $R$ value in vaccinated pigs was demonstrated. In this case, 3 week-old piglets were inoculated with a genotype $1 \mathrm{MLV}$ and divided in 8 groups of five pigs each, as described for unvaccinated piglets in a previous section of the present review. At 35 days postvaccination, $14 \mathrm{NV}$ pigs were experimentally inoculated with a genotype 1 PRRSV isolate that showed $93.4 \%$ of nucleotide similarity with the MLV. Two days later, one challenged pig was introduced into each contact group to expose them to the virus. After 21 days of contact, all NV became viraemic, while only $53 \%$ of $\mathrm{V}$ pigs were detected as such. Moreover, compared to NV pigs, V animals withstood 2 weeks more of contact with the inoculated pig before becoming infected. The $\mathrm{R}$ value was 2.78 $\left(\mathrm{CI}_{95 \%} 2.13-3.43\right)$ in $\mathrm{NV}$ pigs, and $0.53\left(\mathrm{CI}_{95 \%} 0.19-0.76\right)$ in $\mathrm{V}$ animals.

More recently, Rose et al. [83] also showed a significant reduction in PRRSV transmission in vaccinated pigs. In that study, 3 week-old piglets were inoculated with genotype $1 \mathrm{MLV}$, and 12 of them were then challenged with a genotype 1 strain $(92.7 \%$ of sequence homology with 
the MLV) at 31 days post-vaccination. The inoculated pigs were then put in contact with 12 vaccinated piglets for 49 days ( 6 replicates of 2:2 contact trials in total). The experiment was replicated simultaneously with non-vaccinated piglets. Among the contact pigs, the challenge strain was detected in the serum of only one $\mathrm{V}$, whereas all contact $\mathrm{NV}$ were infected. Consequently, the $\mathrm{R}$ was significantly reduced from $5.42\left(\mathrm{CI}_{95 \%} 2.94-9.04\right)$ in $\mathrm{NV}$ pigs to $0.30\left(\mathrm{CI}_{95 \%} 0.05-0.96\right)$ in $\mathrm{V}$ animals.

The results of the abovementioned studies [83, 84] have to be carefully interpreted since the use of other vaccines or challenge isolates may have produced numerically different results. In spite of this, the similar results point towards a potential use of mass vaccination to stop transmission of genotype 1 PRRSV.

It is worth to compare the abovementioned data with the information available for other important and common pig viruses. For example, in Aujeszky's disease virus, de Jong et al. [94] estimated $R$ equal to 10 for naïve pigs with a reduction up to $R=0.5$ in vaccinated pigs. Stegeman et al. [95] estimated $R$ to be equal to 3.4 in single vaccinated pigs and $R=1.5$ in double vaccinated pigs and Bouma et al. [96] estimated R for Aujeszky's disease virus vaccinated pigs to be $<1$. For swine influenza virus, $\mathrm{R}$ was estimated to be around $10[97,98]$ with a reduction of $R$ up to 1 in vaccinated pigs [97]. This comparison of $\mathrm{R}$-values in vaccinated pigs indicates that, at least for the classical genotype 1 subtype 1 isolates of PRRSV, moderate improvements in the vaccine efficacy may result in epidemiologically efficient strategies of vaccination.

\section{PRRSV transmission between farms}

The virus may reach a farm in several ways, but entering infected animals, particularly gilts and sows, is considered the most common route for virus introduction [99-102]. For example, Mortensen et al. [101] associated the spread of type 2 PRRSV in Denmark to the purchase of infected animals without performing quarantine measures. Similarly, in a molecular study in Canada, Thakur et al. [102] found that the predominant relationship between strains within a cluster were the introduction of infected pigs into farms. Also in Canada, Kwong et al. [103] and Rosendal et al. [104] identified the source of gilts as one of the main causes for explaining the spread of different strains in the country.

The use of contaminated semen is also an important route for the introduction of PRRSV into a farm. For instance, Bøtner et al. [105] demonstrated that the clinical outbreaks occurring in Danish PRRS-free breeding herds in July of 1996 were caused by a genotype 2 isolate, previously unrecognised in that country. The virus was found to be $99 \%$ similar to the live vaccine used in boars since December 1995. Semen imported from Germany was also identified as the origin of the introduction of PRRSV in five Swiss herds in November 2012 [106]. Introduction of PRRSV into the farm by semen or by infected gilts is relatively easy to avoid if PRRSV-free sources are used, and adequate testing of boars and quarantine measures are applied.

Several works indicated that trucks, trailers, and other vehicles used for transporting pigs, animal products, feed, offal, and contaminated equipment, are a potential risk for the spread of PRRS. For example, Dee et al. [107] demonstrated that pigs may become infected after been housed for $2 \mathrm{~h}$ in trailers artificially contaminated with $\geq 10^{3} \mathrm{TCID}_{50} / \mathrm{mL}$ of the genotype $2 \mathrm{MN}-30100$ PRRSV isolate. In the same study, transmission of PRRSV was also observed in $3 / 4$ trials where two PRRSV-naïve sentinel pigs were placed for $2 \mathrm{~h}$ in a trailer previously contaminated by experimentally inoculated pigs. Another two works simulated common farm worker behaviour to assess transmission of PRRSV by fomites (boots and containers), vehicle sanitation, transport, and the movement of personnel $[108,109]$. The results showed that the infectious virus can be isolated from the ventral surface of transport vehicles, the truck wash floor, the floor mat of the trailers, drivers' boots, and also from the surface of various types of containers. When the study was conducted during the cold season $\left(<0{ }^{\circ} \mathrm{C}\right)$, infectious virus was recovered from at least one sampling point in 5/10 replicates, and viral RNA was detected at all sampling points in $7 / 10$ replicates [108]. Conversely, in warm weather $\left(>15{ }^{\circ} \mathrm{C}\right)$ the detection rate significantly decreased, suggesting that temperature is critical for virus survival in fomites and therefore, it was assumed that the role of those fomites becomes more important during winter [109].

Treatment of vehicles by washing at high temperature $\left(80{ }^{\circ} \mathrm{C}\right)$ followed by phenol disinfection and overnight drying, was effective for a complete sanitation of trailers. Alternatively, the use of a thermo-assisted drying and decontamination (TADD) system or glutaraldehyde fumigation had an equivalent efficacy to overnight drying for the complete trailer decontamination [110, 111].

Proximity of infected herds has been considered a hazard, resulting in an increased risk of introduction of the virus by aerosol transmission [101, 112, 113]. Nevertheless, the airborne transmission of PRRSV and its implication on the area spread of the disease seems to be dependent on the strain and on environmental factors. Torremorell et al. [114] experimentally demonstrated the airborne transmission of type 2 strain VR-2332 between pigs located $1 \mathrm{~m}$ apart, while transmission did not occur when the MN-1b isolate was used instead. Similarly, 
airborne transmission occurred at distances of 1-2.5 m using the MN-30100 and the VR-2402 isolates, respectively $[115,116]$.

When the aerosol transmission of $\mathrm{MN}-30100$ and VR-2402 isolates was evaluated under field conditions, no positive air samples (by RT-PCR) or infection in susceptible pigs were observed at the different distances between the building where infected pigs were housed and the trailer of susceptible pigs [116, 117]. However, using a source population of 300 grower-finisher pigs experimentally inoculated with the MN-184 isolate, infectious virus was detected from the exhausted air of the facility up to $4.7 \mathrm{~km}$ from the infected herd [118]. Evidence of longdistance airborne dispersion of PRRSV up to $9.1 \mathrm{~km}$ was also demonstrated from a herd experimentally infected with the MN-184 strain, but not for the MN-1-18-2 and MN-1-26-2 PRRSV isolates [119]. In the same study, the viral load in air samples decreased from $10^{4} \mathrm{TCID}_{50} / \mathrm{mL}$ in the proximity of the infected barn to $10^{1} \mathrm{TCID}_{50} / \mathrm{mL}$ at $9.1 \mathrm{~km}$ from the source population, indicating increasing deposition and/or inactivation of the virus with distance. Also, directional winds of low velocity, low temperatures, high relative humidity, and low sunlight levels are factors favourable to the airborne spread [120]. In the conditions of the North American Midwest, [121], it has been shown that air filtration can help to reduce about $80 \%$ of PRRSV introductions in farms of Southern Minnesota and Northern Iowa (USA). Collectively, the abovementioned data indicated that airborne transmission of PRRSV occurs, but is highly influenced by climatic conditions and the strain, and therefore its epidemiological importance may be different in different locations.

The only species known to be susceptible to PRRSV is the pig, either domestic or feral. Only one report indicated a potential role of mallard ducks (Anas platyrhynchos) [122], but subsequent studies did not confirm this [123].

Infection have been confirmed by RT-PCR in wild boars of Italy [124], Germany [125], and Slovakia [126], while serological evidence has been reported in Croatia [127], France [128], Germany [129], and also United States [130]. The detection of PRRSV viruses in wild boars similar to commercial life vaccines indicates that the virus has been probably transmitted from domestic pigs to wild boars $[125,126]$. Thus, the role of feral swine in PRRSV area spread could be considered of limited relevance.

As regards the role of arthropods, Schurrer et al. [131] demonstrated that houseflies can mechanically harbour the virus for up to $48 \mathrm{~h}$, although they did not support PRRSV replication. Actually, contaminated flies were shown to be able to transmit the infection to susceptible pigs [132, 133]. Similarly, Otake et al. [134] demonstrated the transmission of PRRSV from experimentally inoculated pigs to susceptible animals in $2 / 4$ trials. However, in spite of the potential significance of these data, cautious interpretation is advisable, since those studies used artificial exposure models that did not mimic field conditions. Moreover, movements of houseflies between farms are limited by several factors, including the existence of ventilation systems and filters, and the environmental conditions, such as temperature, relative humidity, and wind direction and speed [133]. Taken together, the data indicate that houseflies and mosquitoes can play a role in the spread of the virus within a limited radius $[135,136]$ and, in practical terms, this route has to be considered of minor importance.

The risk of introduction of PRRS in countries free of the disease through importation of contaminated meat and pork products has been also evaluated. In fact, pigs may become infected after ingestion of meat samples negative by virus isolation, but positive by means of RT-PCR [136, 137]. Nevertheless, after conventional post-slaughter handling and freezing, or after traditional manufacturing of pork products, the amount of infectious PRRSV in these products is very low, or even negligible $[138,139]$. Therefore, the likelihood of importing the disease through meat imports is limited, but has to be taken into account [140, 141].

\section{Conclusions}

The epidemiology of PRRSV is far from being fully elucidated, but the accumulated knowledge is enough to identify, at least qualitatively, the main sources of PRRSV infection of a farm, as well as the main mechanisms of transmission within the farm. What is still unknown is what proportion of virus introductions occurs by each route in different epidemiological scenarios. At least for genotype 1 , the quantification of transmission indicates that PRRSV is less transmissible than other viral pathogens of swine, and this may permit transmission to be controlled by means of vaccination, even with the currently available vaccines that only afford a partial protection. A combination of strict biosecurity and rationally designed vaccination programs may be really useful to control PRRS in a farm or on a regional basis.

\footnotetext{
Competing interests

The authors have performed studies on the efficacy of PRRSV vaccines with several vaccine-producing companies. The authors did not receive any salary or received any personal economic compensation for those studies. The contents of the present paper were not revised, approved, contributed or endorsed by any pharmaceutical company.
}

Authors' contributions

Both authors contributed equally to the planning and writing of the present review. Both authors read and approved the final manuscript. 


\section{Acknowledgements}

Our grateful thanks to Anna Vidal for assistance in the editing of the manuscript.

\section{Author details del Vallès, Spain. \\ Funding de Barcelona. \\ Received: 19 May 2016 Accepted: 14 September 2016 \\ Published online: 28 October 2016}

${ }^{1}$ Departament de Sanitat i Anatomia Animals, Universitat Autònoma de Barcelona, Campus UAB, 08193 Cerdanyola del Vallès, Spain. ${ }^{2}$ Centre de Recerca en Sanitat Animal (CReSA)-IRTA. Edifici CReSA, Campus UAB, 08193 Cerdanyola

Emanuela Pileri was supported by a PIF scholarship of Universitat Autònoma

\section{References}

1. Neumann EJ, Kliebenstein JB, Johnson CD, Mabry JW, Bush EJ, Seitzinger AH, Green AL, Zimmerman JJ (2005) Assessment of the economic impact of porcine reproductive and respiratory syndrome on swine production in the United States. J Am Vet Med Assoc 227:385-392

2. Holtkamp DJ, Kliebenstein JB, Neumann EJ, Zimmerman JJ, Rotto HF, Yoder TK, Wang C, Yeske PE, Mowrer CL, Haley CA (2013) Assessment of the economic impact of porcine reproductive and respiratory syndrome virus on United States pork producers. J Swine Health Prod 21:72-84

3. Nieuwenhuis N, Duinhof TF, van Nes A (2012) Economic analysis of outbreaks of porcine reproductive and respiratory syndrome virus in nine sow herds. Vet Rec 170:225

4. Benfield DA, Nelson E, Collins JE, Harris L, Goyal SM, Robison D, Christianson WT, Morrison RB, Gorcyca D, Chladek D (1992) Characterization of swine infertility and respiratory syndrome (SIRS) virus (isolate ATCC VR-2332). J Vet Diagn Invest 4:127-133

5. Bloemraad M, de Kluijver EP, Petersen A, Burkhardt GE, Wensvoort G (1994) Porcine reproductive and respiratory syndrome: temperature and $\mathrm{pH}$ stability of Lelystad virus and its survival in tissue specimens from viraemic pigs. Vet Microbiol 42:361-371

6. Van Alstine WG, Kanitz CL, Stevenson GW (1993) Time and temperature survivability of PRRS virus in serum and tissues. J Vet Diagn Invest 5:621-622

7. Tousignant SJ, Perez AM, Lowe JF, Yeske PE, Morrison RB (2015) Temporal and spatial dynamics of porcine reproductive and respiratory syndrome virus infection in the United States. Am J Vet Res 76:70-76

8. Shirai J, Kanno T, Tsuchiya Y, Mitsubayashi S, Seki R (2000) Effects of chlorine, iodine, and quaternary ammonium compound disinfectants on several exotic disease viruses. J Vet Med Sci 62:85-92

9. Dee SA, Otake S, Deen J (2011) An evaluation of ultraviolet light (UV 254) as a means to inactivate porcine reproductive and respiratory syndrome virus on common farm surfaces and materials. Vet Microbiol 150:96-99

10. Hermann JR, Muñoz-Zanzi CA, Roof MB, Burkhart K, Zimmerman JJ (2005) Probability of porcine reproductive and respiratory syndrome (PRRS) virus infection as a function of exposure route and dose. Vet Microbiol 110:7-16

11. Yoon KJ, Zimmerman JJ, Chang CC, Cancel-Tirado S, Harmon KM, McGinley MJ (1999) Effect of challenge dose and route on porcine reproductive and respiratory syndrome virus (PRRSV) infection in young swine. Vet Res 30:629-638

12. Cutler TD, Wang C, Hoff SJ, Kittawornrat A, Zimmerman JJ (2011) Median infectious dose $\left(\mathrm{ID}_{50}\right)$ of porcine reproductive and respiratory syndrome virus isolate MN-184 via aerosol exposure. Vet Microbiol 151:229-237

13. Hermann JR, Muñoz-Zanzi CA, Zimmerman JJ (2009) A method to provide improved dose-response estimates for airborne pathogens in animals: an example using porcine reproductive and respiratory syndrome virus. Vet Microbiol 133:297-302
14. Benfield D, Nelson C, Steffen M, Rowland R (2000) Transmission of PRRSV by artificial insemination using extended semen seeded with different concentrations of PRRSV. In: Proceedings of the $31^{\text {st }}$ annual meeting of the American association of swine practitioners, Indianapolis, Indiana, pp 405-408

15. Duan X, Nauwynck HJ, Pensaert MB (1997) Virus quantification and identification of cellular targets in the lungs and lymphoid tissues of pigs at different time intervals after inoculation with porcine reproductive and respiratory syndrome virus (PRRSV). Vet Microbiol 56:9-19

16. Otake S, Dee SA, Rossow KD, Joo HS, Deen J, Molitor TW, Pijoan C (2002) Transmission of porcine reproductive and respiratory syndrome virus by needles. Vet Rec 150:114-115

17. Baker SR, Mondaca E, Polson D, Dee SA (2012) Evaluation of a needlefree injection device to prevent hematogenous transmission of porcine reproductive and respiratory syndrome virus. J Swine Health Prod 20:123-128

18. Bierk MD, Dee SA, Rossow KD, Otake S, Collins JE, Molitor TW (2001) Transmission of porcine reproductive and respiratory syndrome virus from persistently infected sows to contact controls. Can J Vet Res 65:261-266

19. Rossow KD, Collins JE, Goyal SM, Nelson EA, Christopher-Hennings J, Benfield DA (1995) Pathogenesis of porcine reproductive and respiratory syndrome virus infection in gnotobiotic pigs. Vet Pathol 32:361-373

20. Cho JG, Dee SA, Deen J, Guedes A, Trincado C, Fano E, Jiang Y, Faaberg K, Collins JE, Murtaugh MP, Joo HS (2006) Evaluation of the effects of animal age, concurrent bacterial infection, and pathogenicity of porcine reproductive and respiratory syndrome virus on virus concentration in pigs. Am J Vet Res 67:489-493

21. Klinge KL, Vaughn EM, Roof MB, Bautista EM, Murtaugh MP (2009) Age-dependent resistance to porcine reproductive and respiratory syndrome virus replication in swine. Virol J 6:177

22. Van Der Linden IFA, Voermans JJM, Van Der Linde-Bril EM, Bianchi ATJ, Steverink PJGM (2003) Virological kinetics and immunological responses to a porcine reproductive and respiratory syndrome virus infection of pigs at different ages. Vaccine 21:1952-1957

23. Díaz I, Gimeno M, Darwich L, Navarro N, Kuzemtseva L, López S, Galindo I, Segalés J, Martín M, Pujols J, Mateu E (2012) Characterization of homologous and heterologous adaptive immune responses in porcine reproductive and respiratory syndrome virus infection. Vet Res 43:30

24. Allende R, Laegreid WW, Kutish GF, Galeota JA, Wills RW, Osorio FA (2000) Porcine reproductive and respiratory syndrome virus: description of persistence in individual pigs upon experimental infection. J Virol 74:10834-10837

25. Horter DC, Pogranichniy RM, Chang C-C, Evans RB, Yoon K-J, Zimmerman JJ (2002) Characterization of the carrier state in porcine reproductive and respiratory syndrome virus infection. Vet Microbiol 86:213-228

26. Wills RW, Doster AR, Galeota JA, Sur J, Osorio FA (2003) Duration of infection and proportion of pigs persistently infected with porcine reproductive and respiratory syndrome virus. J Clin Microbiol 41:58-62

27. Karniychuk UU, Saha D, Vanhee M, Geldhof M, Cornillie P, Caij AB, De Regge N, Nauwynck HJ (2012) Impact of a novel inactivated PRRS virus vaccine on virus replication and virus-induced pathology in fetal implantation sites and foetuses upon challenge. Theriogenol 78:1527-1537

28. Lamontagne L, Pagé C, Larochelle R, Magar R (2003) Porcine reproductive and respiratory syndrome virus persistence in blood, spleen, lymph nodes, and tonsils of experimentally infected pigs depends on the level of CD8high T cells. Viral Immunol 16:395-406

29. Lawson SR, Rossow KD, Collins JE, Benfield DA, Rowland RRR (1997) Porcine reproductive and respiratory syndrome virus infection of gnotobiotic pigs: sites of virus replication and co-localization with MAC-387 staining at 21 days post-infection. Virus Res 51:105-113

30. Sur JH, Cooper VL, Galeota JA, Hesse RA, Doster AR, Osorio FA (1996) In vivo detection of porcine reproductive and respiratory syndrome virus RNA by in situ hybridization at different times postinfection. J Clin Microbiol 34:2280-2286

31. Halbur PG, Paul PS, Frey ML, Landgraf J, Eernisse K, Meng XJ, Andrews J, Lum MA, Rathje JA (1996) Comparison of the antigen distribution of two US porcine reproductive and respiratory syndrome virus isolates with that of the Lelystad virus. Vet Pathol 33:159-170 
32. Beyer J, Fichtner D, Schirrmeier H, Polster U, Weiland E, Wege H (2000) Porcine reproductive and respiratory syndrome virus (PRRSV): kinetics of infection in lymphatic organs and lung. J Vet Med B Infect Dis Vet Public Health 47:9-25

33. Wills RW, Zimmerman JJ, Yoon K-J, Swenson SL, McGinley MJ, Hill HT, Swenson SL, McGinley MJ, Hill HT, Platt KB, Christopher-Hennings J, Nelson EA (1997) Porcine reproductive and respiratory syndrome virus: a persistent infection. Vet Microbiol 55:231-240

34. Benfield DA, Nelson J, Rossow K, Nelson C, Steffen M, Rowland RR (2000) Diagnosis of persistent or prolonged porcine reproductive and respiratory syndrome. Vet Res 31:71

35. Rowland RRR, Lawson S, Rossow KD, Benfield DA (2003) Lymphoid tissue tropism of porcine reproductive and respiratory syndrome virus replication during persistent infection of pigs originally exposed to virus in utero. Vet Microbiol 96:219-235

36. Wills RW, Doster AR, Osorio FA (2002) Transmission of porcine reproductive and respiratory syndrome virus (PRRSV) to age-matched sentinel pigs. J Swine Health Prod 10:161-165

37. Charpin C, Mahé S, Keranflec'h A, Belloc C, Cariolet R, Le Potier MF, Rose N (2012) Infectiousness of pigs infected by the porcine reproductive and respiratory syndrome virus (PRRSV) is time-dependent. Vet Res 43:69

38. Albina E, Madec F, Cariolet R, Torrison J (1994) Immune response and persistence of the reproductive and respiratory syndrome virus in infected pigs and farm units. Vet Rec 134:567-573

39. Christianson WT, Choi CS, Collins JE, Molitor TW, Morrison RB, Joo HS (1993) Pathogenesis of porcine reproductive and respiratory syndrome virus infection in mid-gestation sows and fetuses. Can J Vet Res 57:262-268

40. Christopher-Hennings J, Nelson EA, Hines RJ, Nelson JK, Swenson SL, Zimmerman JJ, Chase CL, Yaeger MJ, Benfield DA (1995) Persistence of porcine reproductive and respiratory syndrome virus in serum and semen of adult boars. J Vet Diagn Invest 7:456-464

41. Christopher-Hennings J, Nelson EA, Nelson JK, Hines RJ, Swenson SL, Hill HT, Zimmerman JJ, Katz JB, Yaeger MJ, Chase CCL, Benfield DA (1995) Detection of porcine reproductive and respiratory syndrome virus in boar semen by PCR. J Clin Microbiol 33:1730-1734

42. Christopher-Hennings J, Holler LD, Benfield DA, Nelson EA (2001) Detection and duration of porcine reproductive and respiratory syndrome virus in semen, serum, peripheral blood mononuclear cells, and tissues from Yorkshire, Hampshire, and Landrace boars. J Vet Diagn Invest 13:133-142

43. Kang I, Ha Y, Kim D, Oh Y, Cho KD, Lee BH, Lim J, Kim SH, Kwon B, Chae C (2010) Localization of porcine reproductive and respiratory syndrome virus in mammary glands of experimentally infected sows. Res Vet Sci 88:304-306

44. Kittawornrat A, Prickett J, Chittick W, Wang C, Engle M, Johnson J, Patnayak D, Schwartz T, Whitney D, Olsen C, Schwartz K, Zimmerman $J$ (2010) Porcine reproductive and respiratory syndrome virus (PRRSV) in serum and oral fluid samples from individual boars: will oral fluid replace serum for PRRSV surveillance? Virus Res 154:170-176

45. Nielsen TL, Nielsen J, Have P, Bækbo P, Hoff-Jørgensen R, Bøtner A (1997) Examination of virus shedding in semen from vaccinated and from previously infected boars after experimental challenge with porcine reproductive and respiratory syndrome virus. Vet Microbiol 54:101-112

46. Prickett J, Simer R, Christopher-Hennings J, Yoon K-J, Evans RB, Zimmerman JJ (2008) Detection of porcine reproductive and respiratory syndrome virus infection in porcine oral fluid samples: a longitudinal study under experimental conditions. J Vet Diagn Invest 20:156-163

47. Rossow KD, Bautista EM, Goyal SM, Molitor TW, Murtaugh MP, Morrison RB, Benfield DA, Collins JE (1994) Experimental porcine reproductive and respiratory syndrome virus infection in 1-, 4-, and 10-week-old pigs. J Vet Diagn Invest 6:3-12

48. Swenson SL, Hill HT, Zimmerman JJ, Evans LE, Landgraf JG, Wills RW, Sanderson TP, McGinley MJ, Brevik AK, Ciszewski DK (1994) Excretion of porcine reproductive and respiratory syndrome virus in semen after experimentally induced infection in boars. J Am Vet Med Assoc 204:1943-1948

49. Wagstrom EA, Chang C, Yoon K, Zimmerman JJ (2001) Shedding of porcine reproductive in mammary gland secretions of sows. Am J Vet Res 62:1876-1880
50. Wills RW, Zimmerman JJ, Yoon KJ, Swenson SL, Hoffman LJ, McGinley MJ, Hill HT, Platt KB (1997) Porcine reproductive and respiratory syndrome virus: routes of excretion. Vet Microbiol 57:69-81

51. Yoon IJ, Joo HS, Christianson WT, Morrison RB, Dial GD (1993) Persistent and contact infection in nursery pigs experimentally infected with porcine reproductive and respiratory syndrome (PRRS) virus. J Swine Health Prod 1:5-8

52. Karniychuk UU, Geldhof M, Vanhee M, Van Doorsselaere J, Saveleva TA, Nauwynck HJ (2010) Pathogenesis and antigenic characterization of a new East European subtype 3 porcine reproductive and respiratory syndrome virus isolate. BMC Vet Res 6:30

53. Frydas IS, Verbeeck M, Cao J, Nauwynck HJ (2013) Replication characteristics of porcine reproductive and respiratory syndrome virus (PRRSV) European subtype 1 (Lelystad) and subtype 3 (Lena) strains in nasal mucosa and cells of the monocytic lineage: indications for the use of new receptors of PRRSV. Vet Res 44:73

54. Frydas IS, Trus I, Kvisgaard LK, Bonckaert C, Reddy VR, Li Y, Larsen LE, Nauwynck HJ (2015) Different clinical, virological, serological and tissue tropism outcomes of two new and one old Belgian type 1 subtype 1 porcine reproductive and respiratory virus (PRRSV) isolates. Vet Res 46:37

55. Cho JG, Dee SA, Deen J, Trincado C, Fano E, Jiang Y, Faaberg K, Murtaugh MP, Guedes A, Collins JE, Joo HS (2006) The impact of animal age, bacterial coinfection, and isolate pathogenicity on the shedding of porcine reproductive and respiratory syndrome virus in aerosols from experimentally infected pigs. Can J Vet Res 70:297-301

56. Thanawongnuwech R, Thacker EL, Halbur PG (1998) Influence of pig age on virus titer and bactericidal activity of porcine reproductive and respiratory syndrome virus (PRRSV)-infected pulmonary intravascular macrophages (PIMs). Vet Microbiol 63:177-187

57. Liu Y, Shi W, Zhou E, Wang S, Hu S, Cai X, Rong F, Wu J, Xu M, Xu M, Li $L$ (2010) Dynamic changes in inflammatory cytokines in pigs infected with highly pathogenic porcine reproductive and respiratory syndrome virus. Clin Vaccine Immunol 17:1439-1445

58. Frydas IS, Nauwynck HJ (2016) Replication characteristics of eight virulent and two attenuated genotype 1 and 2 porcine reproductive and respiratory syndrome virus (PRRSV) strains in nasal mucosa explants. Vet Microbiol 182:156-162

59. Díaz I, Darwich L, Pappaterra G, Pujols J, Mateu E (2006) Different European-type vaccines against porcine reproductive and respiratory syndrome virus have different immunological properties and confer different protection to pigs. Virology 351:249-259

60. Lopez OJ, Oliveira MF, Garcia EA, Kwon BJ, Doster A, Osorio FA (2007) Protection against porcine reproductive and respiratory syndrome virus (PRRSV) infection through passive transfer of PRRSV-neutralizing antibodies is dose dependent. Clin Vaccine Immunol 14:269-275

61. Lowe JE, Husmann R, Firkins LD, Zuckermann FA, Goldberg TL (2005) Correlation of cell-mediated immunity against porcine reproductive and respiratory syndrome virus with protection against reproductive failure in sows during outbreaks of porcine reproductive and respiratory syndrome in commercial herds. J Am Vet Med Assoc 226:1707-1711

62. Osorio FA, Galeota JA, Nelson E, Brodersen B, Doster A, Wills R, Zuckermann F, Laegreid WW (2002) Passive transfer of virus-specific antibodies confers protection against reproductive failure induced by a virulent strain of porcine reproductive and respiratory syndrome virus and establishes sterilizing immunity. Virology 302:9-20

63. Labarque GG, Nauwynck HJ, Van Reeth K, Pensaert MB (2000) Effect of cellular changes and onset of humoral immunity on the replication of porcine reproductive and respiratory syndrome virus in the lungs of pigs. J Gen Virol 81:1327-1334

64. Loving CL, Osorio FA, Murtaugh MP, Zuckermann FA (2015) Innate and adaptive immunity against porcine reproductive and respiratory syndrome virus. Vet Immunol Immunopathol 167:1-14

65. Mateu E, Diaz I (2008) The challenge of PRRS immunology. Vet J 177:345-351

66. Meier WA, Galeota J, Osorio FA, Husmann RJ, Schnitzlein WM, Zuckermann FA (2003) Gradual development of the interferon-gamma response of swine to porcine reproductive and respiratory syndrome virus infection or vaccination. Virology 309:18-31 
67. Murtaugh MP, Genzow M (2011) Immunological solutions for treatment and prevention of porcine reproductive and respiratory syndrome (PRRS). Vaccine 29:8192-8204

68. Plagemann PGW (2006) Neutralizing antibody formation in swine infected with seven strains of porcine reproductive and respiratory syndrome virus as measured by indirect ELISA with peptides containing the GP5 neutralization epitope. Viral Immunol 19:285-293

69. Lager KM, Mengeling WL, Brockmeier SL (1997) Homologous challenge of porcine reproductive and respiratory syndrome virus immunity in pregnant swine. Vet Microbiol 58:113-125

70. Lager KM, Mengeling WL, Brockmeier S (1999) Evaluation of protective immunity in gilts inoculated with the NADC-8 isolate of porcine reproductive and respiratory syndrome virus (PRRSV) and challenge-exposed with an antigenically distinct PRRSV isolate. Am J Vet Res 60:1022-1027

71. Li X, Galliher-Beckley A, Pappan L, Trible B, Kerrigan M, Beck A, Hesse R, Blecha F, Nietfeld JC, Rowland RRR, Shi J (2014) Comparison of host immune responses to homologous and heterologous type II porcine reproductive and respiratory syndrome virus (PRRSV) challenge in vaccinated and unvaccinated pigs. Biomed Res Int 2014:416727

72. Prieto C, Alvarez E, Martínez-Lobo FJ, Simarro I, Castro JM (2008) Similarity of European porcine reproductive and respiratory syndrome virus strains to vaccine strain is not necessarily predictive of the degree of protective immunity conferred. Vet J 175:356-363

73. Scortti M, Prieto C, Simarro I, Castro JM (2006) Reproductive performance of gilts following vaccination and subsequent heterologous challenge with European strains of porcine reproductive and respiratory syndrome virus. Theriogenology 66:1884-1893

74. Done SH, Paton DJ, White ME (1996) Porcine reproductive and respiratory syndrome (PRRS): a review, with emphasis on pathological, virological and diagnostic aspects. Br Vet J 152:153-174

75. Nodelijk G (2002) Porcine reproductive and respiratory syndrome (PRRS) with special reference to clinical aspects and diagnosis. A review. Vet Q 24:95-100

76. Stevenson GW, Alstine WG, Van Kanitz CL, Keffaber KK (1993) Endemic porcine reproductive and respiratory syndrome virus infection of nursery pigs in two swine herds without current reproductive failure. J Vet Diagn Invest 5:432-434

77. Nodelijk G, Nielen M, De Jong MCM, Verheijden JHM (2003) A review of porcine reproductive and respiratory syndrome virus in Dutch breeding herds: population dynamics and clinical relevance. Prev Vet Med 60:37-52

78. Nodelijk G, de Jong MCM, Van Nes A, Vernooy JCM, Van Leengoed LAMG, Pol JMA, Verheijden JHM (2000) Introduction, persistence and fade-out of porcine reproductive and respiratory syndrome virus in a Dutch breeding herd: a mathematical analysis. Epidemiol Infect 124:173-182

79. Evans CM, Medley GF, Creasey SJ, Green LE (2010) A stochastic mathematical model of the within-herd transmission dynamics of porcine reproductive and respiratory syndrome virus (PRRSV): fade-out and persistence. Prev Vet Med 93:248-257

80. Bilodeau R, Archambault D, Vezina SA, Sauvageau R, Fournier M, Dea S (1994) Persistence of porcine reproductive and respiratory syndrome virus infection in a swine operation. Can J Vet Res 58:291-298

81. Diekmann O, Heesterbeek JAP, Metz J (1990) On the definition and computation of the basic reproduction ratio $\mathrm{R} 3$ in models for infectious diseases in heterogeneous populations. J Math Biol 28:365-382

82. Pileri E, Gibert E, Soldevila F, García-Saenz A, Pujols J, Díaz I, Darwich L, Casal J, Martín M, Mateu E (2015) Vaccination with a genotype 1 modified live vaccine against porcine reproductive and respiratory syndrome virus significantly reduces viremia, viral shedding and transmission of the virus in a quasi-natural experimental model. Vet Microbiol 175:7-16

83. Rose N, Renson P, Andraud M, Paboeuf F, Le Potier MF, Bourry O (2015) Porcine reproductive and respiratory syndrome virus (PRRSV) modifiedlive vaccine reduces virus transmission in experimental conditions. Vaccine 33:2493-2499

84. Klinkenberg D, de Bree J, Laevens H, de Jong MCM (2002) Within- and between-pen transmission of classical swine fever virus: a new method to estimate the basic reproduction ratio from transmission experiments. Epidemiol Infect 128:293-299
85. Martínez-Lobo FJ, Díez-Fuertes F, Segalés J, García-Artiga C, Simarro I, Castro JM, Prieto C (2011) Comparative pathogenicity of type 1 and type 2 isolates of porcine reproductive and respiratory syndrome virus (PRRSV) in a young pig infection model. Vet Microbiol 154:58-68

86. Murtaugh MP, Stadejek T, Abrahante JE, Lam TTY, Leung FCC (2010) The ever-expanding diversity of porcine reproductive and respiratory syndrome virus. Virus Res 154:18-30

87. Stadejek T, Porowski M, Pejsak Z (2005) Viraemia and seroconversion in piglets following vaccination with PRRSV-EU type vaccine-a field observation. Bull Vet Inst Pulawy 49:273-277

88. Martelli P, Gozio S, Ferrari L, Rosina S, De Angelis E, Quintavalla C, Bottarelli E, Borghetti P (2009) Efficacy of a modified live porcine reproductive and respiratory syndrome virus (PRRSV) vaccine in pigs naturally exposed to a heterologous European (Italian cluster) field strain: clinical protection and cell-mediated immunity. Vaccine 27:3788-3799

89. Cano JP, Dee SA, Murtaugh MP, Trincado CA, Pijoan CB (2007) Effect of vaccination with a modified-live porcine reproductive and respiratory syndrome virus vaccine on dynamics of homologous viral infection in pigs. Am J Vet Res 68:565-571

90. Linhares DCL, Cano JP, Wetzell T, Nerem J, Torremorell M, Dee SA (2012) Effect of modified-live porcine reproductive and respiratory syndrome virus (PRRSv) vaccine on the shedding of wild-type virus from an infected population of growing pigs. Vaccine 30:407-413

91. Cano JP, Dee SA, Murtaugh MP, Pijoan C (2007) Impact of a modifiedlive porcine reproductive and respiratory syndrome virus vaccine intervention on a population of pigs infected with a heterologous isolate. Vaccine 25:4382-4391

92. Nodelijk G, De Jong MCM, Van Leengoed LAMG, Wensvoort G, Pol JMA, Steverink PJGM, Verheijden JHM (2001) A quantitative assessment of the effectiveness of PRRSV vaccination in pigs under experimental conditions. Vaccine 19:3636-3644

93. Mondaca-Fernández E, Meyns T, Muñoz-Zanzi C, Trincado C, Morrison RB (2007) Experimental quantification of the transmission of porcine reproductive and respiratory syndrome virus. Can J Vet Res 71:157-160

94. De Jong MC, Kimman TG (1994) Experimental quantification of vaccineinduced reduction in virus transmission. Vaccine 12:761-766

95. Stegeman A, Van Nes A, de Jong MC, Bolder FW (1995) Assessment of the effectiveness of vaccination against pseudorabies in finishing pigs. Am J Vet Res 56:573-578

96. Bouma A, De Jong MC, Kimman TG (1997) Comparison of two pseudorabies virus vaccines, that differ in capacity to reduce virus excretion after a challenge infection, in their capacity of reducing transmission of pseudorabies virus. Vet Microbiol 54:113-122

97. Romagosa A, Allerson M, Gramer M, Joo HS, Deen J, Detmer S, Torremorell M (2011) Vaccination of influenza a virus decreases transmission rates in pigs. Vet Res 42:120

98. Allerson M, Deen J, Detmer SE, Gramer MR, Joo HS, Romagosa A, Torremorell M (2013) The impact of maternally derived immunity on influenza A virus transmission in neonatal pig populations. Vaccine. 31:500-505

99. Carlsson U, Wallgren P, Renström LHM, Lindberg A, Eriksson H, Thorén P, Eliasson-Selling L, Lundeheim N, Nörregard E, Thörn C, Elvander M (2009) Emergence of porcine reproductive and respiratory syndrome in Sweden: detection, response and eradication. Transbound Emerg Dis 56:121-131

100. Larochelle R, D'Allaire S, Magar R (2003) Molecular epidemiology of porcine reproductive and respiratory syndrome virus (PRRSV) in Québec. Virus Res 96:3-14

101. Mortensen S, Stryhn H, Sogaard R, Boklund A, Stärk KDC, Christensen J, Willeberg P (2002) Risk factors for infection of sow herds with porcine reproductive and respiratory syndrome (PRRS) virus. Prev Vet Med 53:83-101

102. Thakur KK, Revie CW, Hurnik D, Poljak Z, Sanchez J (2015) Simulation of between-farm transmission of porcine reproductive and respiratory syndrome virus in Ontario, Canada using the North American animal disease spread model. Prev Vet Med 118:413-426

103. Kwong GP, Poljak Z, Deardon R, Dewey CE (2013) Bayesian analysis of risk factors for infection with a genotype of porcine reproductive and respiratory syndrome virus in Ontario swine herds using monitoring data. Prev Vet Med 110:405-417 
104. Rosendal T, Dewey C, Friendship R, Wootton S, Young B, Poljak Z (2014) Spatial and temporal patterns of porcine reproductive and respiratory syndrome virus (PRRSV) genotypes in Ontario, Canada, 2004-2007. BMC Vet Res 10:83

105. Bøtner A, Strandbygaard B, Sørensen KJ, Have P, Madsen KG, Madsen ES, Alexandersen S (1997) Appearance of acute PRRS-like symptoms in sow herds after vaccination with a modified live PRRS vaccine. Vet Rec 141:497-499

106. Nathues C, Perler L, Bruhn S, Suter D, Eichhorn L, Hofmann M, Nathues H, Baechlein C, Ritzmann M, Palzer A, Grossmann K, Schüpbach-Regula G, Thür B (2014) An outbreak of porcine reproductive and respiratory syndrome virus in Switzerland following import of boar semen. Transbound Emerg Dis 63:e251-e261

107. Dee SA, Deen J, Otake S, Pijoan C (2004) An experimental model to evaluate the role of transport vehicles as a source of transmission of porcine reproductive and respiratory syndrome virus to susceptible pigs. Can J Vet Res 68:128-133

108. Dee SA, Deen J, Rossow K, Wiese C, Otake S, Joo HS, Pijoan C (2002) Mechanical transmission of porcine reproductive and respiratory syndrome virus throughout a coordinated sequence of events during cold weather. Can J Vet Res 66:232-239

109. Dee SA, Deen J, Rossow K, Weise C, Eliason R, Otake S, Joo HS, Pijoan C (2003) Mechanical transmission of porcine reproductive and respiratory syndrome virus throughout a coordinated sequence of events during warm weather. Can J Vet Res 67:12-19

110. Dee SA, Deen J, Burns D, Douthit G, Pijoan C (2004) An assessment of sanitation protocols for commercial transport vehicles contaminated with porcine reproductive and respiratory syndrome virus. Can J Vet Res 68:208-214

111. Dee SA, Torremorell M, Thompson B, Deen J, Pijoan C (2005) An evaluation of thermo-assisted drying and decontamination for the elimination of porcine reproductive and respiratory syndrome virus from contaminated livestock transport vehicles. Can J Vet Res 69:58-63

112. Lager KM, Mengeling WL, Wesley RD (2002) Evidence for local spread of porcine reproductive and respiratory syndrome virus. J Swine Health Prod 10:167-170

113. Velasova M, Alarcon P, Williamson S, Wieland B (2012) Risk factors for porcine reproductive and respiratory syndrome virus infection and resulting challenges for effective disease surveillance. BMC Vet Res 8:184

114. Torremorell M, Pijoan C, Janni K, Walker R, Joo HS (1997) Airborne transmission of Actinobacillus pleuropneumoniae and porcine reproductive and respiratory syndrome virus in nursery pigs. Am J Vet Res 58:828-832

115. Trincado C, Dee SA, Jacobson L, Otake S, Rossow KD, Pijoan C (2004) Attempts to transmit porcine reproductive and respiratory syndrome virus by aerosols under controlled field conditions. Vet Rec 154:294-297

116. Wills RW, Zimmerman JJ, Swenson SL, Yoon KJ, Hill HT, Bundy DS, McGinley MJ (1997) Transmission of PRRS virus by direct, close, or indirect contact. J Swine Health Prod 5:213-218

117. Otake S, Dee SA, Jacobson L, Torremorell M, Pijoan C (2002) Evaluation of aerosol transmission of porcine reproductive and respiratory syndrome virus under controlled field conditions. Vet Rec 150:804-808

118. Dee SA, Otake S, Oliveira S, Deen J (2009) Evidence of long distance airborne transport of porcine reproductive and respiratory syndrome virus and Mycoplasma hyopneumoniae. Vet Res 40:39

119. Otake S, Dee SA, Corzo C, Oliveira S, Deen J (2010) Long-distance airborne transport of infectious PRRSV and Mycoplasma hyopneumoniae from a swine population infected with multiple viral variants. Vet Microbiol 145:198-208

120. Dee SA, Otake S, Deen J (2010) Use of a production region model to assess the efficacy of various air filtration systems for preventing airborne transmission of porcine reproductive and respiratory syndrome virus and Mycoplasma hyopneumoniae: results from a 2-year study. Virus Res 154:177-184

121. Alonso C, Murtaugh MP, Dee SA, Davies PR (2013) Epidemiological study of air filtration systems for preventing PRRSV infection in large sow herds. Prev Vet Med 112:109-117
122. Zimmerman JJ, Yoon KJ, Pirtle EC, Wills RW, Sanderson TJ, McGinley MJ (1997) Studies of porcine reproductive and respiratory syndrome (PRRS) virus infection in avian species. Vet Microbiol 55:329-336

123. Trincado C, Dee SA, Rossow KD, Halvorson D, Pijoan C (2004) Evaluation of the role of mallard ducks as vectors of porcine reproductive and respiratory syndrome virus. Vet Rec 154:233-237

124. Bonilauri P, Merialdi G, Dottori M, Barbieri I (2006) Presence of PRRSV in wild boar in Italy. Vet Rec 158:107-108

125. Reiner G, Fresen C, Bronnert S, Willems H (2009) Porcine reproductive and respiratory syndrome virus (PRRSV) infection in wild boars. Vet Microbiol 136:250-258

126. Vilcek S, Molnar L, Vlasakova M, Jackova A (2015) The first detection of PRRSV in wild boars in Slovakia. Berl Munch Tierarztl Wochenschr 128:31-33

127. Roic B, Jemersic L, Terzic S, Keros T, Balatinec J, Florijancic T (2012) Prevalence of antibodies to selected viral pathogens in wild boars (Sus scrofa) in Croatia in 2005-2006 and 2009-2010. J Wild Dis 48:131-137

128. Albina E, Mesplède A, Chenut G, Le Potier MF, Bourbao G, Le Gal S, Leforban Y (2000) A serological survey on classical swine fever (CSF), Aujeszky's disease (AD) and porcine reproductive and respiratory syndrome (PRRS) virus infections in French wild boars from 1991 to 1998. Vet Microbiol 77:43-45

129. Oslage U, Dahle J, Müller T, Kramer M, Beier D, Liess B (1994) Prevalence of antibodies against the viruses of European swine fever, Aujeszky's disease and porcine reproductive and respiratory syndrome in wild boars in the federal states Sachsen-Anhalt and Brandenburg. Dtsch Tierarztl Wochenschr 101:33-38

130. Baroch JA, Gagnon CA, Lacouture S, Gottschalk GM (2015) Exposure of feral swine (Sus scrofa) in the United States to selected pathogens. Can J Vet Res 79:74-78

131. Schurrer JA, Dee SA, Moon RD, Murtaugh MP, Finnegan CP, Deen J, Kleiboeker SB, Pijoan CB (2005) Retention of ingested porcine reproductive and respiratory syndrome virus in houseflies. Am J Vet Res 66:1517-1525

132. Otake S, Dee SA, Rossow KD, Moon RD, Trincado C, Pijoan C (2003) Transmission of porcine reproductive and respiratory syndrome virus by houseflies. Vet Rec 152:73-76

133. Otake S, Dee SA, Moon RD, Rossow KD, Trincado C, Pijoan C (2004) Studies on the carriage and transmission of porcine reproductive and respiratory syndrome virus by individual houseflies (Musca domestica). Vet Rec 154:80-85

134. Otake S, Dee SA, Rossow KD, Moon RD, Pijoan C (2002) Mechanical transmission of porcine reproductive and respiratory syndrome virus by mosquitoes, Aedes vexans (Meigen). Can J Vet Res 66:191-195

135. Moon RD (2002) Muscid flies, Muscidae. In: Durden LA, Mullen GR (eds) Medical and veterinary entomology, chapter 16. Academic Press, New York

136. Schurrer JA, Dee SA, Moon RD, Rossow KD, Mahlum C, Mondaca E, Otake S, Fano E, Collins JE, Pijoan C (2006) Spatial dispersal of porcine reproductive and respiratory syndrome virus-contaminated flies after contact with experimentally infected pigs. Am J Vet Res 65:1284-1292

137. Magar R, Larochelle R (2004) Evaluation of the presence of porcine reproductive and respiratory syndrome virus in pig meat and experimental transmission following oral exposure. Can J Vet Res 68:259-266

138. Van Der Linden IFA, Van Der Linde-Bril EM, Voermans JJM, Van Rijn PA, Pol JMA, Martin R, Steverink PJGM (2003) Oral transmission of porcine reproductive and respiratory syndrome virus by muscle of experimentally infected pigs. Vet Microbiol 97:45-54

139. Guarino H, Cox RB, Goyal SM, Patnayak DP (2013) Survival of porcine reproductive and respiratory syndrome virus in pork products. Food Environ Virol 5:157-161

140. EFSA Panel on Animal Health and Welfare (2005) The probability of transmission of porcine reproductive and respiratory syndrome virus (PRRSv) to naive pigs via fresh meat. EFSA J 239:1-85

141. Hall W, Neumann E (2015) Fresh pork and porcine reproductive and respiratory syndrome virus: factors related to the risk of disease transmission. Transbound Emerg Dis 62:350-366 